\title{
KEPEMILIKAN MANAJERIAL, KEPEMILIKAN INSTITUSIONAL, DEWAN KOMISARIS DAN AGENCY COST
}

\section{MANAGERIAL OWNERSHIP, INSTITUTIONAL OWNERSHIP, BOARD OF COMMISSIONERS AND AGENCY COST}

\author{
Dhehani Jafaria Hatang ${ }^{1}$, Dini Wahjoe Hapsari² \\ 1Telkom University \\ 2Telkom University \\ Email : dhehanihatang@gmail.com dan dinihapsari@telkomuniiversity.ac.id
}

\begin{abstract}
ABSTRAK
Tujuan dari penelitian ini adalah untuk menguji pengaruh kepemilikan manajerial, kepemilikan institusional dan dewan komisaris terhadap agency cost. Pengambilan sampel dalam penelitian ini menggunakan metode purposive sampling. Dari metode tersebut diperoleh 20 perusahaan pertambangan. Penelitian ini menggunakan data sekunder dari laporan tahunan perusahaan pertambangan yang terdaftar di Bursa Efek Indonesia pada tahun 2015-2018. Model analisis yang digunakan adalah analisis statistik descriptive, uji asumsi klasik, analisis regresi data panel, pengujian simultan dibuktikan dengan uji $F$ dan pengujian parsial dengan uji t. Hasil penelitian menunjukkan bahwa secara simultan kepemilikan manajerial, kepemilikan institusional dan dewan komisaris berpengaruh terhadap agency cost. Secara parsial kepemilikan manajerial berpengaruh dan mempunyai hubungan arah positif terhadap agency cost.
\end{abstract}

Kata Kunci: Dewan Komisaris, Kepemilikan Institusional, Kepemilikan Manajerial

\begin{abstract}
The purpose of this study is to examine the effect of managerial ownership, institutional ownership and the board of commissioners on agency cost. This study used a purposive sampling method. From this method obtained 20 mining companies. This study uses secondary data from annual reports of mining companies listed on the Indonesia Stock Exchange in 20152018. The analysis model used is descriptive statistical analysis, classic assumption test, panel data regression analysis, simultaneous testing proved by $F$ test and partial testing by $t$ test. The result of this study showed that simultaneous, managerial ownership, institutional ownership and board of commissioners had an effect on the agency cost. Partially, managerial ownership has a significant effect and a positive direction on the agency cost.
\end{abstract}

Keyword: Board of Commissioners, Institutional Ownership, Managerial Ownership 


\section{PENDAHULUAN}

Dalam menjalankan perusahaan, terdapat dua pihak, yaitu principal atau pemegang saham dan agent atau manajemen. Pemegang saham adalah pemasok modal yang mengharapkan return atas investasi yang mereka tanam sedangkan manajemen merupakan pengelola yang ditunjuk oleh pemegang saham untuk menjalankan perusahaan. Berdasarkan teori keagenan, terdapat pemisah antara pemilik dan manajemen perusahaan. Lukviarman (2016) mengemukakan bahwa para ahli teori keagenan menggunakan asumsi bahwa kedua pihak tersebut (pemilik dan manajemen) memiliki kepentingan masing-masing dan kepentingan tersebut lebih banyak mengalami perbedaan dari sudut pandang keduanya.

Adanya kepentingan yang berbeda diantara kedua pihak dapat menimbulkan masalah keagenan atau yang biasa disebut dengan agency problem. Masalah keagenan ini kemudian memicu perusahaan untuk mengeluarkan biaya dalam mengatasinya, biaya itu disebut sebagai biaya keagenan atau agency cost. Untuk mengukur biaya keagenan dapat menggunakan Asset Turnover Ratio (ATO). Asset Turnover Ratio (ATO) merupakan rasio efesiensi biaya yang diproksi dengan rasio biaya operasi. Rasio biaya operasi digunakan untuk mengukur seberapa efektif perusahaan dalam mengendalikan biaya opersionalnya. Menurut Setyaningsih (2017) perputaran asset yang tinggi mencerminkan bahwa penggunaan asset oleh manajemen tidak boros, dengan kata lain asset turnover yang tinggi menunjukkan agency cost yang rendah.

Salah satu kasus biaya keagenan terjadi pada PT. Pertamina Persero, pada akhir November 2015 diberitakan bahwa ada dugaan kegiatan korupsi di anak perusahaan Pertamina yaitu Pertamina Trading Limited (Petral) yang membuat reputasi Petral menjadi buruk dan membawa beban kerugian bagi Pertamina. Oleh karena itu, pada akhirnya Petral dibubarkan padahal Petral selama ini memegang monopoli kegiatan ekspor dan impor minyak mentah dan bahan bakar Indonesia. Karena dugaan tersebut, Pertamina melakukan audit investigasi untuk membuktikan penyimpangan dan fraud yang dilakukan oleh Petral atau pihak-pihak lainnya. Audit investigasi oleh PT Pertamina karena adanya dugaan korupsi pada anak perusahaannya (Petral) termasuk jenis biaya keagenan, yaitu monitoring cost. Sedangkan kerugian PT Pertamina atas kegiatan korupsi pada Petral merupakan biaya keagenan jenis residual loss.

Biaya keagenan yang dipicu karena adanya masalah keagenan bisa disebabkan karena penerapan mekanisme corporate governance perusahaan yang lemah dan kurang efektif. Menurut Mustapha dan Ahmad (2011) dalam Pratiwi dan Yulianto (2016) jika pelaksanaan corporate governance perusahaan lemah maka perusahaan akan menanggung biaya keagenan yang tinggi. Corporate Governance merupakan sistem atau seperangkat peraturan yang mengatur hubungan antara pihak-pihak internal dengan eksternal perusahaan serta mengelola perusahaan yang dirancang secara professional berdasarkan prinsipnya yaitu transparani, akuntabilitas, tanggungjawab, independen, kewajaran dan kesetaraan. Kemampuan perusahaan dalam menerapkan mekanisme good corporate governance secara maksimal efeknya dapat mengurangi sifat oppurtunistik manajer dan mengurangi biaya keagenan. Penulis ingin meneliti pengaruh implementasi mekanisme good corporate governance yaitu kepemilikan manajerial, kepemilikan institusional dan dewan komisaris dengan biaya keagenan.

Berdasarkan hasil penelitian penelitian Schäuble (2019), menunjukkan hasil bahwa kepemilikan manajerial berpengaruh negatif terhadap biaya agensi, kepemilikan manajerial efektif dalam mengurangi biaya agensi. Berbeda dengan hasil penelitian Pratiwi dan Julianto (2016) mengungkapkan bahwa kepemilikan manajerial tidak berpengaruh signifikan terhadap biaya agensi. Sementara hasil penelitian Owusu dan Weir (2018) menyatakan bahwa kepemilikan institusional berpengaruh negatif terhadap biaya agensi, berbeda dengan Handoko (2014) dan Pratiwi dan Yulianto (2016) hasilnya menunjukkan bahwa kepemilikan institusional tidak secara 
signifikan mempengaruhi biaya agensi. Krisnauli (2018) menjelaskan hasil penelitian menunjukkan hubungan negatif antara dewan komisaris dan biaya agensi. Berbeda dengan hasil penelitian Fatahillah (2018) yang menyatakan bahwa ukuran dewan komisaris tidak berpengaruh pada biaya agensi.

\section{LANDASAN TEORI}

\section{Agency Theory}

Agency theory merupakan hubungan kontrak antara agent dan principal dalam menjalankan perusahaan. Teori ini timbul karena adanya fenomena pemisahan kepentingan. Principal merupakan pemegang saham yang menunjuk agent atau manajemen yang profesional dalam bidangnya untuk menjalankan usaha yang bertujuan agar pemegang saham memperoleh keuntungan semaksimal mungkin dari saham modal yang ia tanam. Agents sebagai pengelola perusahaan mempunyai keleluasaan dalam menjalankan manajemen perusahaan sehingga semakin besar laba perusahaan maka semakin besar keuntungan yang mereka dapatkan. Principal bertugas untuk mengawasi dan memonitor manajemen dalam menjalankan perusahaan dan memastikan bahwa manajemen bertindak demi kepentingan perusahaan bukan kepentingan pribadi.

\section{Agency Problem}

Pemisahan kepentingan antara principal dan agent dapat menimbulkan masalah agency atau agency problem. Manajemen tidak bertindak untuk kepentingan perusahaan melainkan kepentingan diri sendiri. Agency problem merupakan risiko dari adanya perbedaan kepentingan antara pemegang saham dan manajemen. Agency problem bisa timbul karena adanya asimetri informasi (information asymmetry). Asimetri informasi merupakan suatu kondisi dimana manajemen lebih banyak mengetahui informasi tentang internal perusahaan dibandingkan principal.

\section{Agency Cost}

Adanya agency problem memicu timbulnya biaya yang harus dikeluarkan oleh perusahaan untuk mengatasinya. Biaya itu disebut dengan agency cost. Agency cost merupakan biaya yang ditimbulkan dari adanya gap informasi antara manajemen dengan shareholders (Abdillah, 2019:6). Menurut Decow et al (2005) dalam Sari et al (2015:2) agency cost adalah sejumlah biaya yang dikeluarkan untuk mendapatkan sejumlah informasi yang berasal dari pihak internal, informasi tersebut memiliki peran penting didalam proses pengambilan keputusan dalam berinvestasi. Definisi agency cost menurut Sartono (2012:12) yaitu biaya yang harus dikeluarkan perusahaan untuk memperkecil masalah keagenan.

Menurut Jensen dan Meckling (1976) terdiri dari:

1) Monitoring cost yaitu biaya monitoring dikeluarkan oleh prinsipal untuk memonitor perilaku agent, termasuk juga usaha untuk mengendalikan perilaku agent.

2) Bonding expenditures yaitu biaya yang dikeluarkan oleh agent untuk menjamin bahwa agent tidak akan menggunakan tindakan tertentu yang akan merugikan prinsipal atau untuk menjamin bahwa principal akan diberi kompensasi jika ia tidak mangambil banyak tindakan.

3) Residual loss merupakan penurunan tingkat kesejahteraan prinsipal maupun agent setelah adanya agency relationship. 


\section{Good Corporate Governance}

Salah satu cara untuk mengurangi biaya keagenan adalah dengan menerapkan good corporate governance. Good corporate governance adalah suatu sistem yang mengarahkan dan mengendalikan perusahaan untuk meningkatkan keberhasilan dan nilai perusahaan serta memenuhi tujuan stockholder maupun stakeholder (Sadewa dan Yasa, 2016:18). Organization for Economic Corporation and Development (OECD) mendefinisikan Corporate Governance sebagai sekumpulan hubungan antar pihak manajemen perusahaan, board, pemegang saham, dan pihak lain yang mempunyai kepentingan dengan perusahaan. Dapat disimpulkan bahwa good corporate governance merupakan sistem yang terkonsep terdiri dari pihak manajemen, pemegang saham dan board untuk mengelola perusahaan agar tercapainya kegiatan usaha yang efektif dan efisien dalam mencapai tujuan perusahaan.

Mekanisme good corporate governance dibagi menjadi dua, yaitu mekanisme internal dan eksternal. Mekanisme internal adalah cara untuk mengendalikan dan mengelola perusahaan melalui struktur dan proses internal seperti rapat umum pemegang saham (RUPS), dewan direksi dan dewan komisaris. Mekanisme eksternal atau yang juga disebut mekanisme pengendalian pasar adalah mekanisme yang terbentuk oleh hubungan perusahaan dengan pasar atau dengan mekanisme yang berasal dari pihak luar perusahaan, seperti pasar modal, pasar kontrol perusahaan dan pemegang saham. Pada penelitian ini, mekanisme internal berfokus pada kepemilikan manajerial dan dewan komisaris sedangkan dari mekanisme eksternal berfokus pada kepemilikan institusional.

\section{Pengembangan Hipotesis}

\section{Pengaruh Kepemilikan Manajerial terhadap Agency Cost}

Kepemilikan manajerial merupakan kepemilikan dari pihak manajemen yang secara aktif ikut dalam pengambilan keputusan perusahaan, yakni direktur dan komisaris Safari et al (2018:664) artinya agent yang memiliki saham perusahaan mempunyai kedudukan ganda, sebagai agent yang dimana bertugas untuk mengelola perusahaan juga sebagai principal atau sebagai pemilik perusahaan. Kedudukan sebagai pengelola sekaligus pemilik perusahaan membuat manajemen bertindak lebih hati-hati dalam mengambil keputusan dan bertindak karena mereka akan menanggung konsekuensi atas keputusan yang diambil dan tentu tidak ingin merugikan diri sendiri.

Semakin besar kepemilikan manajerial dalam suatu perusahaan dapat mendorong manajemen untuk lebih giat dalam memenuhi kepentingan dirinya sendiri, sebagai pemegang saham dan berusaha untuk meningkatkan pemanfaatan asset (Putra et al. 2018:1925). Hal ini dapat menyelaraskan kepentingan antara manajemen dan pemegang saham yang dapat mencegah konflik keagenan dan mengurangi agency cost atau biaya keagenan. Pernyataan ini sejalan dengan hasil penelitian Jonas Schäuble, 2019 yang menunjukkan bahwa kepemilikan manajerial efektif dalam mengurangi biaya keagenan dan adanya hubungan negatif antara kepemilikan manajerial dengan agency cost

\section{H1: Kepemilikan manajerial memiliki hubungan negatif dengan agency cost}

\section{Pengaruh Kepemilikan Institusional terhadap Agency Cost}

Menurut Putri \& Sukartha (2016:1427) kepemilikan institusional merupakan suatu bentuk kepemilikan saham dimana pemegang sahamnya berbentuk institusi. Pihak institusional diantaranya perusahaan asuransi, bank, perusahaan-perusahaan investasi dan kepemilikan oleh 
institusi-institusi lain. Brigham dan Ehrhardt (2011) menyatakan bahwa pemegang saham institusional memiliki kekuatan yang lebih besar jika dibandingkan dengan investor individual yang hanya memiliki saham perusahaan yang kecil, sehingga pemegang saham institusional dapat mengawasi manajemen.

Pengawasan oleh pemegang saham institusi diharapkan mampu mendorong manajemen untuk lebih mementingkan kinerja perusahaan dengan baik dan menghasilkan perputaran asset yang tinggi. Kepemilikan institusional mengindikasikan kemampuannya untuk memonitor manajemen agar tidak berusaha untuk bertindak demi kentingkan kepentingan dirinya sendiri atau berbuat curang karena kepemilikan ini mewakili suatu sumber kekuasaan yang dapat digunakan untuk mengontrol tindakan/keputusan manajemen, sehingga akan mengurangi agency cost perusahaan. Hal ini sejalan dengan hasil penelitian Krisnauli (2014) bahwa kepemilikan institusional berpengaruh negatif terhadap biaya keagenan yang artinya semakin tinggi kepemilikan institusional dalam perusahaan maka biaya keagenan perusahaan akan semakin rendah.

\section{H2: Kepemilikan institusional memiliki hubungan negatif dengan agency cost}

\section{Pengaruh Dewan Komisaris terhadap Agency Cost}

Dewan komisaris merupakan perwakilan dari pemegang saham, baik pengendali maupun minoritas, bisa dikatakan bahwa dewan komisaris merupakan alat pengendalian dan merupakan mekanisme internal corporate governance yang penting (Handoko, 2014:227). Dewan komisaris bertugas untuk melakukan pengawasan secara umum dan/atau khusus sesuai dengan anggaran dasar serta memberi nasihat kepada Direksi. Dalam kata lain, dewan komisaris mempunyai tanggung jawab atas pelaksaan usaha perusahaan.

Fungsi dewan sebagai pengawas manajemen dapat dicerminkan dari rapat-rapat yang dilakukan dewan dan berkaitan dengan pengendalian manajemen yang lebih berkualitas. Jumlah rapat dewan komisaris terbukti secara empiris meningkatkan perputaran aset perusahaan (manajemen aset) yang artinya manajemen memanfaatkan asset secara efektif. (Hadiprajitno, 2013, p. 122). Sesuai pasal 31 peraturan Otoritas Jasa Keuangan NOMOR 33 /POJK.04/2014, Dewan Komisaris wajib mengadakan rapat paling kurang 1 (satu) kali dalam 2 (dua) bulan.

Menurut Rismayani dan Nanda (2018:49), semakin tinggi frekuensi pertemuan dewan komisaris dapat meningkatkan kinerja perusahaan. Dengan demikian adanya pertemuan dewan komisaris merupakan wadah untuk melakukan pengarahan, memantau, dan juga mengevaluasi pelaksanaan kegiataan perusahaan oleh manajemen untuk meningkatkan pemanfaatan aset perusahaan. Hal ini dapat mencegah perbuatan oportunistik dan curang oleh manajemen yang dapat menyebabkan agency problem, karena itu semakin tinggi frekuensi pertemuan dewan komisaris dipercaya dapat mengurangi agency cost. Pernyataan ini sejalan dengan hasil penelitian oleh Krisnauli (2018) yang menunjukkan adanya hubungan negatif antara dewan komisaris dan biaya keagenan.

\section{H3: Dewan komisaris memiliki hubungan negatif dengan agency cost}

\section{METODOLOGI PENELITIAN}

\section{Jenis dan Sumber Data Penelitian}

Jenis data yang digunakan dalam penelitian ini adalah data sekunder, yaitu data-data yang disediakan oleh pihak lain dan tidak berasal dari sumber langsung. Data yang diperoleh berupa laporan tahunan perusahaan pertambangan yang dipublikasikan oleh Bursa Efek Indonesia (BEI) 
tahun 2015 - 2018. Pengambilan sampel dilakukan dengan metode purposive sampling. Jumlah populasi 42 yang memenuhi kriteria sebanyak 20 perusahaan, maka data penelitian $20 \times 4$ tahun yaitu 80 data.

\section{Metode Analisis dan Hipotesisi Penelitian}

Pengujuan pertama dengan uji statistik deskriptif, Kemudian pengujian asumsi klasik sebagai salah satu syarat untuk bisa menggunakan persamaan regresi data panel adalah terpenuhinya uji asumsi klasik. Dua uji asumsi klasik dalam penelitian ini meliputi multikolinearitas dan heteroskedastisitas. Penjelasan masing-masing pengujian asumsi klasik akan diuraikan seperti di bawah ini. Lanjutan pengujian untuk metode analisis yang digunakan untuk menguji pengaruh variabel bebas terhadap terikat dengan Uji T, Uji F dan Uji Determinasi.

\section{Operasional Variabel Penelitian}

Variabel merupakan suatu gambaran keadaan objek penelitian secara abstrak, oleh karena itu dalam suatu penelitian perlu dijabarkan sehingga variabel yang diteliti dapat diukur dalam proses yang biasa disebut operasional variabel (Indrawati, 2015:124). Penelitian ini menggunakan dua variable utama yaitu variable independen (variable bebas) dan variable dependen (variable terikat). Berikut adalah pemaparan dari masing-masing variabel:

\section{Agency Cost}

Agency cost merupakan biaya yang ditimbulkan dari adanya gap informasi antara manajemen dengan shareholders. (Abdillah, 2019, p. 6). Agency cost dapat diukur dengan menggunakan proksi asset turnover (ATO) (Setyaningsih, 2017:89-90). Asset turnover (ATO) merupakan rasio efesiensi biaya artinya perusahaan yang memiliki ATO rendah menunjukkan bahwa manajer tidak secara efektif dalam mengelola asset yang optimal yang berarti agency cost perusahaan tersebut tinggi.

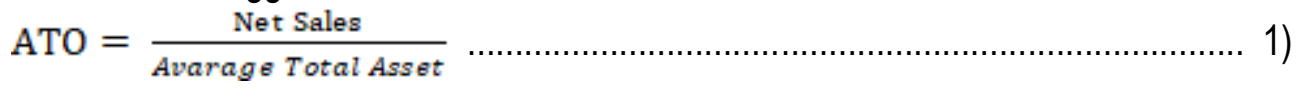

\section{Kepemilikan Manajerial}

Kepemilikan manajerial merupakan pemegang saham dari pihak manajemen yang secara aktif ikut dalam pengambilan keputusan perusahaan, yakni direktur dan komisaris (Safari et al, 2018:663). Kepemilikan manajerial dalam suatu perusahaan dapat mencegah adanya tindakan yang bersifat oportunistik dari manajemen karena posisinya yang juga sebagai pemegang saham tentu tidak ingin merugikan diri sendiri. Menurut Sugiarto (2009:59) kepemilikan manajerial merupakan perbandingan jumlah saham yang dimiliki oleh orang dalam (insiders) dengan jumlah saham yang dimiliki oleh investor yang dirumuskan seperti berikut:

$$
K P M=\frac{\text { Jumlah Saham Manajerial }}{\text { Total Jumlah Saham Beredar }}
$$

\section{Kepemilikan Institusional}

Kepemilikan institusional merupakan suatu bentuk kepemilikan saham dimana pemegang sahamnya berbentuk institusi atau bersifat pasif dalam kegiatan operasional perusahaan (Putri dan Sukartha, 2016:1427). Adanya pemegang saham institusional akan mendorong peningkatan pengawasan yang optimal dalam suatu perusahaan, kepemilikan institusional merupakan salah 
satu mekanisme corporate governance yang memiliki arti penting dalam memonitor tindakan manajemen. Berikut rumus yang digunakan untuk mengukur kepemilikan institusional:

$$
K P I=\frac{\text { Jumlah Saham Institusional }}{\text { Total Jumlah Saham Beredar }}
$$

\section{Dewan Komisaris}

Dewan komisaris merupakan sebuah dewan mempunyai peran dalam suatu perusahaan untuk mengawasi implementasi kebijakan direksi (Krisnauli, 2014:3). Dewan komisaris adalah alat pengendalian dan merupakan elemen yang penting dalam mekanisme internal corporate governance (Handoko, 2014:244). Fungsi pengawasan dewan komisaris dapat dicerminkan oleh frekuensi rapat dewan komisaris seperti rumus berikut ini (Hadiprajitno, 2013:122)

$$
\text { DK }=\text { Jumlah Rapat Dewan Komisaris }
$$

\section{HASIL PENELITIAN DAN PEMBAHASAN}

Hasil Penelitian

\section{Statistik Deskriptif}

Tabel 1. Hasil Statistik Deskriptif

\begin{tabular}{lcccc}
\hline & $\begin{array}{c}\text { Kepemilkan } \\
\text { Manajerial } \\
\left(\mathrm{X}_{1}\right)\end{array}$ & $\begin{array}{c}\text { Kepemilikan } \\
\text { Institusional } \\
\left(\mathrm{X}_{2}\right)\end{array}$ & $\begin{array}{c}\text { Dewan } \\
\text { Komisaris } \\
\left(\mathrm{X}_{3}\right)\end{array}$ & $\begin{array}{c}\text { Agency Cost } \\
(\mathrm{ATO}) \\
(\mathrm{Y})\end{array}$ \\
\hline Mean & 0.0249 & 0.5995 & 9.1125 & 0.5964 \\
Std. Deviation & 0.0443 & 0.2533 & 4.2337 & 0.5031 \\
Maksimum & 0.1452 & 0.9739 & 24 & 2.3123 \\
Minimum & 0.0000 & 0.0000 & 2 & 0.000 \\
\hline
\end{tabular}

Berdasarkan hasil pengujian statistik deskriptif yang ditunjukkan pada tabel 1 , dapat diketahui besarnya nilai rata rata kepemilikan manajerial perusahaan sektor pertambangan yang terdaftar di Bursa Efek Indonesia tahun 2015-2018 adalah sebesar 0.0249 yang berarti bahwa secara keseluruhan kepemilikan manajerial dalam perusahaan sektor pertambangan sudah dalam keadaan baik karena nilai rata-rata lebih besar dari pada batas minimal yaitu sebesar 0,000 . Selain itu dapat diketahui dari tabel 1 , variabel kepemilikan manajerial memiliki standar deviasi sebesar 0.0443 yang lebih besar dari nilai mean sehingga dapat dikatakan data tersebut bervariasi atau tidak berkelompok.

Kepemilikan institusional perusahaan sektor pertambangan yang terdaftar di Bursa Efek Indonesia tahun 2015-2018 memiliki rata-rata sebesar 0.5995 yang berarti bahwa secara keseluruhan kepemilikan institusional dalam perusahaan sektor pertambangan sudah dalam keadaan baik karena nilai rata-rata lebih besar dari pada batas minimal yaitu sebesar 0,000. Selain itu dapat diketahui dari tabel 1 , variabel kepemilikan institusional memiliki standar deviasi sebesar 0.2533 yang lebih kecil dari nilai mean sehingga dapat dikatakan data tersebut berkelompok atau tidak bervariasi.

Hasil pengujian statistik deskriptif pada tabel 1 menunjukkan rata-rata dari frekuensi rapat dewan komisaris perusahaan sektor pertambangan yang terdaftar di Bursa Efek Indonesia tahun 2015-2018 adalah sebesar 9.1125, nilai ini lebih besar dari batas minimum yaitu 2 yang berarti secara keseluruhan frekuensi rapat dewan komisaris dalam perusahaan sektor pertambangan 
sudah dalam keadaan baik. Standar deviasi dari frekuensi rapat dewan komisaris sebesar 4.2337 lebih kecil dari nilai mean artinya data tersebut bervariasi atau tidak berkelompok.

Pada tabel 1 dapat diketahui nilai rata-rata dari asset turnover ratio (ATO) sebagai proksi agency cost adalah sebesar 0.5970 dan nilai minimum sebesar 0.000 . Nilai rata-rata lebih besar dari nilai minimum berarti data secara keseluruhan asset turnover ratio (ATO) pada perusahaan yang menjadi sampel di penelitian ini sudah dalam keadaan baik. Standar deviasi dari asset turnover ratio (ATO) yaitu sebesar 0.5031 nilai ini lebih kecil dari nilai rata-rata berarti data tersebut bervariasi atau tidak berkelompok.

\section{UJI ASUMSI KLASIK Uji Multikolinearitas}

\section{Tabel 2. Hasil Uji Multikolinearitas}

Variance Inflation Factors

Date: 12/15/19 Time: 19:27

Sample: 180

Included observations: 80

\begin{tabular}{cccc}
\hline \hline Variable & $\begin{array}{c}\text { Coefficient } \\
\text { Variance }\end{array}$ & $\begin{array}{c}\text { Uncentered } \\
\text { VIF }\end{array}$ & $\begin{array}{c}\text { Centered } \\
\text { VIF }\end{array}$ \\
\hline \hline C & 0.396247 & 21.66262 & NA \\
KPM & 0.001928 & 2.022012 & 1.012351 \\
KPI & 0.018703 & 1.428257 & 1.003745 \\
DK & 0.075738 & 19.22834 & 1.009307 \\
\hline \hline
\end{tabular}

Sumber: Output Eviews 9, 2019

Berdasarkan hasil output diatas, dapat dilihat dalam penelitian memiliki ini memiliki nilai VIF lebih kecil dari 10 sehingga pada penelitian ini tidak terjadi multikolinearitas antar variabel independen.

\section{Uji Heteroskedastitas}

Tabel 3. Hasil Uji Heteroskedasitas

Heteroskedasticity Test: White

\begin{tabular}{llll}
\hline \hline F-statistic & 1.785354 & Prob. F(3,76) & 0.1571 \\
Obs*R-squared & 5.266785 & Prob. Chi-Square(3) & 0.1533 \\
Scaled explained SS & 10.06551 & Prob. Chi-Square(3) & 0.0180 \\
\hline
\end{tabular}

Sumber: Output Eviews 9, 2019

Berdasarkan tabel diatas, nilai probability Chi-square adalah 0,1533 lebih dari $\alpha=0,05$, sehingga ditarik kesimpulkan bahwa data-data tersebut tidak terjadi gejala heteroskedastisitas. 


\section{Model Regresi Data Panel}

Penelitian ini menggunakan teknik analisis regresi data panel dengan menggunakan Software Eviews 9. Dalam teknik analisis ini, terdapat tiga model yang dapat dipakai yaitu common effect model fixed effect model dan random effect model. Berdasarkan hasil pengujian model yang telah dilakukan (Uji Chow, Hausman dan LM) maka Common Effect Model merupakan model yang sesuai untuk penelitian ini. Tabel berikut ini menyajikan hasil Common Effect Model menggunakan Software Eviews 9:

\section{Tabel 4. Hasil Common Effect Model}

Dependent Variable: $Y$

Method: Panel Least Squares

Date: 12/15/19 Time: 18:55

Sample: 20152018

Periods included: 4

Cross-sections included: 20

Total panel (balanced) observations: 80

\begin{tabular}{lrlrl}
\hline \hline \multicolumn{1}{c}{ Variable } & Coefficient & Std. Error & t-Statistic & Prob. \\
\hline \hline C & -2.336253 & 0.629481 & -3.711393 & 0.0004 \\
KPM & -0.111934 & 0.043906 & -2.549404 & 0.0128 \\
KPI & -0.085129 & 0.136759 & -0.622474 & 0.5355 \\
DK & 0.467061 & 0.275205 & 1.697142 & 0.0938 \\
\hline \hline R-squared & 0.104196 & Mean dependent var & -0.955206 \\
Adjusted R-squared & 0.068836 & S.D. dependent var & 1.253601 \\
S.E. of regression & 1.209685 & Akaike info criterion & 3.267304 \\
Sum squared resid & 111.2137 & Schwarz criterion & 3.386406 \\
Log likelihood & -126.6922 & Hannan-Quinn criter. & 3.315055 \\
F-statistic & 2.946671 & Durbin-Watson stat & 0.964497 \\
Prob(F-statistic) & 0.038139 & & \\
\hline
\end{tabular}

Berdasarkan tabel 4, analisis regresi diatas diperoleh berdasarkan nilai asset $\overline{\text { turning ratio }}$ (ATO) yang mana nilai dari asset turning ratio (ATO) ini bertolak belakang dengan agency cost. Maka, persamaan regresi agency cost adalah sebagai berikut.

\section{$\mathrm{Y}=2.337+0.112 \mathrm{KPM}+0.085 \mathrm{KPI}-0.467 \mathrm{DK}$}

Berdasarkan tabel diatas dapat dilihat bahwa hasil uji koefisien determinasi $\left(R^{2}\right)$ menunjukkan nilai adjusted $R$-squared sebesar 0.0688 atau $6.88 \%$. Hal tersebut dapat disimpulkan bahwa variabel independen yang terdiri dari kepemilikan manajerial, kepemilikan institusional dan dewan komisaris dapat menjelaskan variabel dependen yaitu agency cost sebesar 0.0688 atau $6.88 \%$ sedangkan sisanya yaitu 0.9312 atau $93.12 \%$ dipengaruhi oleh variabel lain diluar penelitian. Hasil pengujian simultan menunjukkan bahwa probability $\mathrm{F}$ ststistic sebesar 0.0381 atau nilai signifikan kurang dari $\alpha=0.05$. Demikian dapat ditarik kesimpulan bahwa kepemilikan manajerial, kepemilikan institusional dan dewan komisaris secara bersamasama berpengaruh signifikan terhadap agency cost. 


\section{PEMBAHASAN}

Pada tabel 4 dapat dilihat bahwa hasil uji parisal (uji t) variabel kepemilikan manajerial secara signifikan bernilai 0.0128 atau lebih kecil dari $a=0.05$, yang berarti bahwa kepemilikan manajerial memiliki pengaruh secara signifikan terhadap agency cost. Nilai koefisien regresi kepemilikan manajerial sebesar 0.1119 yang menunjukkan arah positif terhadap agency cost artinya terdapat hubungan yang searah antara kepemilikan manajerial dengan agency cost. Dimana jika nilai kepemilikan manajerial mengalami pengingkatan satu satuan maka agency cost akan meningkat sebesar 0.1119 atau semakin tinggi kepemilikan manajerial maka agency cost akan meningkat. Hasil ini tidak sesuai dengan hipotesis yang sudah dibangun sebelumnya yaitu ada nya hubungan arah negatif antara kepemilikan manajerial dengan agency cost.

Hubungan positif berarti ketika kepemilikan manajerial tinggi maka agency cost meningkat yang dicerminkan oleh efesiensi pemanfaatan aktiva dari manajemen rendah. Hubungan ini menunjukkan bahwa kepemilikan manajerial belum dapat berfungsi sepenuhnya sebagai mekanisme untuk meningkatkan efesiensi pemanfaatan aktiva perusahaan dan belum dapat menekan diskresi manajerial. Hubungan positif antara kepemilikan manajerial dengan agency cost dapat terjadi karena pihak manajemen yang memiliki saham dalam jumlah kecil (minoritas), akan membuat pemegang saham lain berusaha mengawasi dan mempengaruhi pengambilan keputusan manajemen sehingga proses pengambilan keputusan menjadi tidak fleksibel dan lambat. Hasil ini sesuai dengan hasil penelitian oleh Jelinek dan Stuerke 2009 dalam Pratiwi dan Yulianto, 2016 bahwa kepemilikan manajerial berpengaruh signifikan dan dapat meningkatkan agency cost.

Pada tabel 4 dapat dilihat bahwa hasil uji parisal (uji t) kepemiikan institusional secara signifikan bernilai 0.5355 atau lebih besar dari $\alpha=0.05$, yang berarti bahwa kepemilikan institusional tidak memiliki pengaruh agency cost perusahaan pertambangan yang terdaftar di Bursa Efek Indonesia pada tahun 2015-2018. Hal ini menunjukkan bahwa pemegang saham institusional pada perusahaan pertambangan yang terdaftar di Bursa Efek Indonesia pada tahun 2015-2018 tidak dapat mengintervensi manajemen dalam memanfaatkan asset dan mengurangi agency cost.

Hasil ini tidak sesuai dengan hipotesis yang sudah dibangun sebelumnya, dimana variabel kepemilkan institusional memiliki hubungan positif terhadap agency cost (ATO). Hasil statistik deskriptif menunjukkan bahwa variasi kepemilikan institusional 0.9739 dan 0.000 dangan standar deviasi yang kecil sebesar 0.2533 mendukung terjadinya perbedaan koefisien pada penelitian ini. Tanda yang berlawanan menunjukkan bahwa kepemilikan institusional belum dapat berfungsi sepenuhnya sebagai mekanisme untuk meningkatkan efesiensi pemanfaatan aktiva perusahaan dan belum dapat menekan manajerial. Hasil penelitian ini didukung oleh penelitian dari Pratiwi dan Yulianto, 2016 bahwa biaya keagenan perusahaan tidak mampu dikurangi melalui kepemilikan institusional dan kepemilikan institusional tidak mempengaruhi kinerja manajemen.

Pada tabel 4 dapat dilihat bahwa hasil uji parisal (uji t) rapat dewan komisaris secara signifikan bernilai 0.0938 atau lebih besar dari $\alpha=0.05$, yang berarti bahwa jumlah rapat dewan komisaris tidak memiliki pengaruh terhadap agency cost (ATO) perusahaan pertambangan yang terdaftar di Bursa Efek Indonesia pada tahun 2015-2018. Penyebab tidak berpengaruhnya dewan komisaris terhadap agency cost (ATO) adalah karena rapat dewan komisaris dinilai tidak memiliki kekuatan dalam melakukan intervensi kepada pihak manajemen. Walaupun dilakukan rapat sesering mungkin tetapi pihak manajemen tidak dapat mengimplementasikan arahan dan evaluasi untuk menjalankan perusahaan dengan efisien dan efektif, maka rapat dewan komisaris tidak dapat mempengaruhi pihak manajemen dalam meningkatkan aset turning rasio sebagai proksi agency cost. 


\section{REKOMENDASI KEBIJAKAN}

\section{Rekomendasi}

Berdasarkan hasil pengujian data yang diproses eviews9 sesuai dengan tujuan penelitian ini, maka rekomendasi hasil penelitian ini antara lain:

1. Berdasarkan hasil dari pengujian simultan, variabel independen dalam penelitian ini yaitu kepemilikan manajerial, kepemilikan institusional dan dewan komisaris secara bersamasama berpengaruh secara simultan terhadap agency cost pada perusahaan pertambangan yang terdaftar di Bursa Efek Indonesia pada tahun 2015-2018. Kombinasi antara variabel independen mampu menjelaskan variasi dari agency cost sebesar $6.88 \%$.

2. Berdasarkan hasil pengujian parsial:

a. Kepemilikan manajerial secara parsial memiliki pengaruh yang positif dan signifikan terhadap agency cost pada perusahaan sektor pertambangan yang terdaftar di Bursa Efek Indonesia periode 2015-2018.

b. Kepemilikan institusional secara parsial tidak memiliki pengaruh terhadap agency cost pada perusahaan sektor pertambangan yang terdaftar di Bursa Efek Indonesia periode 2015-2018.

c. Dewan komisaris secara parsial tidak memiliki pengaruh signifikan terhadap agency cost pada perusahaan sektor pertambangan yang terdaftar di Bursa Efek Indonesia periode 2015-2018.

\section{Kebijakan}

Bedasarkan hasil dan interpretasi penelitian ini, maka peneliti memberikan saran sebagai rekomendasi kebijakan antara lain

1. Penelitian ini memiliki keterbatasan yaitu kurangnya jumlah perusahaan yang bisa dijadikan sample, sehingga untuk peniliti selanjutnya dapat mengganti objek penelitian lain yang memiliki jumlah perusahaan lebih banyak sehingga dapat memperbanyak sampel untuk dapat lebih menggambarkan keadaan tingkat biaya keagenan. Variabel independen pada penelitian ini hanya mampu menjelaskan variasi dari agency cost sebesar $6.88 \%$ maka penelitian selanjutnya diharapkan menambah variable lain yang dapat menjelaskan agency cost seperti leverage.

2. Dalam penelitian ini dijelaskan bahwa kepemilikan manajerial berpengaruh signifikan dengan arah positif terhadap agency cost. Hal itu bisa menjadi pertimbangan perusahaan untuk mempertimbangkan jumlah kepemilikan manajerial untuk memitigasi agency cost.

\section{DAFTAR PUSTAKA}

Abdillah, M. R. (2019). Pengaruh Strategi Bisnis Terhadap Internet Financial Reporting Dan Agency Cost Sebagai Variabel Intervening. Dinamikaekonomi Jurnal Ekonomi Dan Bisnis, 12(1).

Basuki, A. T., \& Prawoto, N. (2016). Analisis Regresi Dalam Penelitian Ekonomi \& Bisnis : Dilengkapi Aplikasi Spss \& Eviews. Depok: Pt Rajagrafindo Persada.

Brigham, E. F., \& Houston, J. F. (2006. ). Dasar-Dasar Manajemen Keuangan (Vol. 1). (A. A. Yulianto, Trans.) Jakarta: PT. Salemba Empat. 
Fatahillah, S. (2018). Pengaruh Mekanisme Good Corporate Governance terhadap Biaya Agensi pada Perusahaan Manufaktur yang Terdaftar di Bursa Efek Indonesia tahun 2013-2017.

Hadiprajitno, P. B. (2013, May). Struktur Kepemilikan, Mekanisme Tata Kelola Perusahaan, Dan Biaya Keagenan Di Indonesia. 9(2), 97-127.

Handoko, J. (2014). Pengaruh Struktur modal Mekanisme corporate Governance terhadap Agency Cost Perusahaan LQ45 di BEI Tahun 2013.

Indrawati. (2015). Metode Penelitian Manajemen dan Bisnis. Bandung: Refika Aditama.

Krisnauli, P. B. (2014). Pengaruh Mekanisme Tata Kelola Perusahaan dan Kepemilikan Manajerial terhadap Agency Cost. 2(2), 1-13.

Lukviarman, N. (2016). Corporate Governance. Jakarta: Era Adicitra Intermedia .

Pratiwi, R., \& Yulianto, A. (2016). Pengaruh Struktur Kepemilikan dan Komisaris Independen terhadap Biaya Keagenan Perusahaan Yang Masuk Dalam Indonesia Most Trusted Company. Management Analysis Journal; ISSN 2502-1451, 5(3), 215-228.

Putra, D. A., Aminah, W., \& Kristanti, F. T. (2018). Pengaruh Kepemilikan Manajerial, Komite Audit dan Dewan Komisaris Independen terhadap Manajemen Laba. 5(2), 2193-2201.

Putri, M. A., \& Sukartha, I. M. (2016, May). Pengaruh Mekanisme Corporate Governance pada Agency Cost. 15(2).

Rismayani , G., \& Nanda, U. L. (2018, August). Pengaruh Dewan Komisaris, Dewan Pengawas Syariah (DPS) dan Direksi terhadap Kinerja Maqasid Syariah. 4(2), 40-55.

Sadewa, N., \& Yasa, G. W. (2016). Pengaruh Corporate Governance dan Leverage terhadap Agency Cost. Jurnal IImiah Akuntansi dan Bisnis, 17.

Safari , R. K., Suzan, L., \& Aminah, W. (2018, Maret). Pengaruh Kepemilikan Manajerial, Kepemilikan Institusional dan Penilaian Aset Tidak Berwujud terhadap Nilai Perusahaan. Vol.5(No.1), 682.

Sari, Y. H., Yuhelmi, \& Dharma, S. (2015). Pengaruh Leverage, Size, Managerial Ownership dan Dewan Komisaris Terhadap Agency Costs Pada Lima Kelompok Industri di Bursa Efek Indonesia. 6(2).

Sartono, A. (2012). Manajemen Keuangan dan Aplikasi (Vol. 4). Yogyajakarta: BPFE.

Schäuble, J. (2019). The impact of external and internal corporate governance mechanisms on agency costs. 19(1), 1-22.

Setyaningsih, N. D. (2017). Determinan Mekanisme Internal Corporate Governance terhadap Agency Cost. 8(1), 88.

Setyaningsih, N. D. (2017). Determinan Mekanisme Internal Corporate Governance terhadap Agency Cost. 8(1), 88. 